\title{
Using The Resource-Based View To Explore The Jamaican Health Tourism Sector As A Service: A Preliminary Examination
}

\author{
Dawn H. Pearcy, Ph.D., Eastern Michigan University, USA \\ Daria Gorodnia, Student, Eastern Michigan University, USA \\ Jacquelyn Lester, Graduate Student, Wayne State University, USA
}

\begin{abstract}
Tourism plays a key role in the economy of the Caribbean Island of Jamaica, generating substantial revenues and contributing to employment. Jamaica endeavors to grow its economy and achieve developed nation status within the next two decades and is looking to tourism to help the country reach this goal. Specifically, Jamaica seeks to diversify its tourism offering by making a significant foray into what has been projected to be a highly lucrative health tourism market. While the potential for Jamaica to capitalize on the opportunities presented by this sector is substantial, much remains undiscovered about Jamaica's current position as well as what might be required to advance the nation in this area. The purpose of this paper is to provide a preliminary examination of Jamaica's health tourism sector within a resource-based view framework, highlighting the manner in which customers might serve as valuable resources and to examine a key element of the service delivery process.
\end{abstract}

Keywords: Jamaica; Medical Tourism; Wellness Tourism; Resource-Based View; Service Delivery

\section{INTRODUCTION}

ccording to the United Nations World Tourism Organization (UNWTO), tourism ranks as one of the world's largest sectors (UNWTO 2008), generating substantial revenues and serving as a significant source of employment in many nations. Forecasts suggest that international arrivals will increase to approximately 1.6 billion by the year 2020 (Chen, et al. 2011). Given the financial impact and potential of tourism, the sector plays a key role in the economy of various nations. This is undoubtedly the case on Jamaica, a small island developing state in the Caribbean, which has drawn visitors from various parts of the world for several decades.

While historical figures and forecasts for the sheer number of people engaging in international travel are encouraging, the variety of tourism offerings and diverse locales available to consumers create a highly competitive business landscape. For a destination to be competitive and contribute to both local and national economic viability, its offerings, attractions and resources must generate national and international recognition (Yoon, et al. 2011). This is not an easy task, and Chen, et al. (2011) note that this can be particularly challenging for some small Island (developing) states. However, Scheyvens and Momsen (2008) point to the resilience and adaptability of island states as characteristics that contribute to their ability to compete effectively within the tourism sector.

In relatively recent years, Jamaica's ability to employ this resilience and adaptability effectively has been tested. While the future appears to be promising for the Jamaican tourism sector, with expected growth to US\$9.09 billion in economic activity by 2017, up from US $\$ 4.57$ billion in 2007 (Vision 2030 Jamaica 2010); research indicates that emerging forms of tourism based on evolving customer demand offer additional opportunities for competitive advantage and success. One such area of tourism is health tourism. 
The broad sector of health tourism encompasses two distinct components - medical tourism and wellness tourism (Voigt, et al. 2010; Smith \& Puczkó 2009). Medical tourism can be defined as "travel to destinations to undergo medical treatments such as surgery or other special interventions" (Smith \& Puczkó 2009, p. 101) and the outcomes are "expected to be substantial and long-term" (Connell 2006, p. 1093). Wellness tourism has been conceptualized as "the sum of all the relationships resulting from a journey by people whose primary motive is to maintain or promote their health and well-being and who stay at least one night at a facility that is specifically designed to enable and enhance people's physical, psychological, spiritual and/or social well-being" (Voigt, et al. 2010, p. 9).

A recent study forecasts that spending on medical tourism attributed to American travels alone will double over 2010 figures to $\$ 80$ billion annually in 2017 (Gan and Frederick 2011). With Americans comprising the majority of Jamaica's tourism market, the country has much to gain with a foray into the health tourism sector. The Jamaican government acknowledges the importance of tourism in its future success and prosperity as well as the need for it to diversify its offerings to include emerging forms of tourism such as health tourism. In fact, the importance of this area is evidenced by a 97-page report on tourism included in the document, "Vision 2030 Jamaica" - a governmental plan intended to help the country achieve developed status by the year 2030.

In order for Jamaica to maximize the current opportunities and future potential of the health tourism sector, it will be necessary for the country to make use of various assets in the broad areas of human and natural resources, to name a few. The resource-based view (RBV) of the firm is a business management philosophy that has been widely researched and applied in practice. The basic premise of the theory is that firms gain competitive advantage by maximizing its resources (Wernerfelt, 1984; Conner, 1991; Peteraf, 1993). These resources include both tangible and intangible assets possessed by and available to the firm. In addition, these resources are tied to the firm in a permanent or at least semi-permanent way (Wernerfelt 1984; Amit and Schoemaker 1993).

While the RBV is most commonly applied to individual firms, the unit of analysis in this paper will be at the national level. Dyer and Singh (1998) support the analysis of resources across organizational boundaries and their paper points to studies, which suggest that multiple firms may gain competitive advantage when forming a network and bringing together their resources in inimitable ways (Asanuma 1989). In summary, Dyer and Singh (1998) suggest that groups of firms or networks can take advantage of collective resources in the attempt to secure competitive advantage. Therefore, the rationale of this paper is that multiple groups of networks constitute an entire sector of a country, and is a valid unit of analysis.

\section{PURPOSE}

It appears that Jamaica anticipates that health tourism will play a vital role in its economy going forward and the country's desire to advance this sector is evident. However, little academic research exists to analyze the health tourism sector in Jamaica and enhance our understanding in this area. Therefore, the purpose of this paper is to provide a preliminary examination of the Jamaican health tourism sector within the RBV framework, highlighting the manner in which customers might serve as valuable resources and to examine a key element of the service delivery process. The goal of this exploratory study is to contribute to a foundation for further research on the sector and to provide some early implications for practice.

\section{LITERATURE OVERVIEW}

\section{Health Tourism Trends}

Travel for the purpose of enhancing one's well-being is not a recent phenomenon, in fact it can be traced back to at least the $18^{\text {th }}$ and $19^{\text {th }}$ centuries when Europeans traveled near and far to engage in seaside medical and spa tourism and to seek out enhanced well-being through spiritual enlightenment (Smith and Kelly 2006). Despite a history that spans at least a few centuries, the concept of healthcare tourism, which ultimately became known as health tourism was largely unexamined in academic literature until the early 1980s (Goodrich 1993). In recent years, the prevalence of various health tourism offerings such as spas, retreats, holistic and wellness centers is unprecedented (Smith and Kelly 2006). 
Citing Goodrich \& Goodrich (1987), Bennett, et al. (2004, p. 122) defined health tourism as "the attempt on the part of a tourist facility or destination to attract tourists by deliberately promoting its health-care services and facilities, in addition to its regular tourist amenities. Hall (1992, p. 123) conceptualizes health tourism as comprising three elements: "staying away from home, health as the primary motive and occurring in a leisure setting". A review of the literature reveals that although many definitions of health tourism exist, there is general agreement that the health tourism sector can be divided into two distinct realms - medical tourism and wellness tourism. The two realms differ in that medical tourists travel for the purpose of gaining relief from an ailment or accessing therapies/treatments to cure a specific medical issue, whereas an individual who engages in wellness travel is typically in overall good health and seeks treatments and experiences to maintain their well-being (Smith \& Puczkó 2009).

According to the literature, many different motivations for consumers to engage in medical tourism exist. According to Gan and Frederick (2011), rising healthcare costs in one's home country coupled with consumers' lack of medical insurance coverage have contributed to the prevalence of medical tourism. Connell (2006) cites: information available via the Internet, the emergence of healthcare "brokers", improving healthcare systems in some nations, increased marketing of healthcare (along with tourism) as an enterprise, increased privatization of healthcare and growing interest in elective surgeries and procedures as additional factors contributing to the increase in medical tourism figures. A number of factors have contributed to the popularity of the wellness tourism sector as well. As the large segment of baby-boomers in the United States ages, they are increasingly seeking out spa treatments and other experiences intended to provide stress-reduction, physical fitness and pampering in the pursuit of improving their overall mental and physical well-being (McNeil and Ragins 2005). Additional factors influencing the prevalence of the wellness tourism sector include consumers' desires to access alternative healing therapies and increased willingness to spend money on their health and well-being (Voigt, et al. 2010).

\section{Resource-based View}

Businesses in all sectors are concerned with long-term financial success. Most often, a pathway to this success includes fending off industry-wide competitors, while seeking to gain and maintain a substantial customer base. The term competitive advantage has been conceptualized as "the ability gained through attributes and resources to perform at a higher level than others in the same industry or market" (Chacarbaghi and Lynch 1999, p. 45). The RBV of the firm conceptualizes the firm as a "bundle" of resources, with each firm having (combination of) resources that are specific to it and distinct from others" (Wernerfelt 1995). Barney (1991, p. 105) further note that the sheer existence of resources does not necessarily lead to competitive advantage and that firms can only enjoy competitive advantage if "resources and their combinations are: valuable, rare, imperfectly imitable, and imperfectly substitutable".

\section{The Role of the Customer in the Service Experience}

The Gouthier and Schmid (2003) study notes that various types of resources exist and they undertake research to establish whether customers can be construed as resources. They point out that with few exceptions (e.g., Oliver 1997; Rouse and Daellenbach 1999), prior research had not considered customers as vital resources to the firm and assert that the focus on an "inter-firm view" of resources such as corporate culture or company innovativeness as a possible reason for this. Gouthier and Schmid (2003) further note that researchers such as Freiling (1997) and Hogan and Armstrong (2001) utilized the RBV, with customers and customer relationships as valuable resources.

When it comes to service firms, customers interact before, during, and after the service is rendered (Gouthier and Schmid 2003). Gouthier and Schmid (2003) define the elements of the "production process" for services as the pre-production input process, the end-production input process, the pre-production throughput process, the end-production throughput process and the output. During these interactions, both the customer and the service provider form expectations about each other, including customer expectations about the service provider's behavior and performance and the service provider's expectations about the role of the customer (Bitner et al. 1990; Webb 2000). In their attempt to demonstrate how the customer can serve as a resource to the firm, Gouthier and Schmid (2003) identify six different, highly interconnected roles that the service customer can play. 
According to Gouthier and Schmid (2003), the service customer can assume a co-designer role; in that customers often voice their opinions to service providers in the form of compliments or complaints. This means that firms can use customers as vital sources of input in the planning process and the introduction of new services or the improvement of existing ones. The implication is that in an early state of the service production process, the customer can serve as a "productive resource" available to the firm (Bitner, et al. 1997).

The second role that the service customer can assume is the co-production factor role. This occurs when the customer provides the co-production factor by providing some of his/her own goods or the customer constitutes the co-production factor by becoming involved either actively or passively in the rendering of the service (Gouthier and Schmid 2003).

A service customer can play the third role of "co-interactor" by interconnecting with the service provider or other third parties (such as customers). This means that in order for the service to be provided, the customer must combine his/her activities with the activities of the service provider and/or others. This role acknowledges that the service and service provider are inseparable (Gouthier and Schmid 2003).

The fourth role of the customer is to serve as a "substitute for leadership" (Schneider and Bowen, 1995). Gouthier and Schmid (2003) note, this implies that the customer can assume some of the functions typically assumed by a firm's managers. This includes actions that influence the drive, attitudes, and behaviors of front-line service employees and could even extend to establishing tasks and duties. According to Gouthier and Schmid (2003), the aforementioned roles combined support the notion that the service customer assumes the role of a "coproducer".

The fifth role of the service customer is straightforward - customers pay for services to be consumed, there they play the role of buyer. Finally, the service customer can play the vital role of "co-marketer" (Storbacka, 1993). In the realm of services, the co-marketer is important because consumers perceive a high level of risk due to their intangible nature (Zeithaml, 1981). As such, word-of-mouth or getting a referral from an experienced service customer plays a vital role in helping customers reduce this risk (Zeithaml, 1981).

Gouthier and Schmid (2003) note that not all service customers play all of the above roles in each service encounter. In fact, the only roles that are required are the co-production factor role, the co-interactor role and the buyer role. They consider these the basic roles because the customer has to interact with the service provider and purchase the service. Gouthier and Schmid (2003) refer to the other roles as add-on roles, as they are discretionary roles that customers might or might not take on.

Gouthier and Schmid (2003) conclude that although customers are not possessed or controlled by the service firm; they are connected in a semi-permanent manner because they become an integral part of the service production and delivery process when they perform the aforementioned basic roles. In addition, the researchers assert, "Customers are not purely external to the firm; they become - at least for some time - part of the firm. Therefore, we will interpret customers as being "boundary resources" of the service firm" (Gouthier and Schmid 2003, p. 126). Finally, Gouthier and Schmid (2003) reinforce their premise that customers can serve as valuable resources and a source of competitive advantage by referring to RBV research that supports the notion that customers and customer relationships can be valuable (e.g., Ostrom and Roundtree 1998), rare (e.g., Srivastava, et al. 2001), imperfectly imitable (e.g., Hogan and Armstrong 2001) and imperfectly substitutable (e.g., Montgomery 1995).

\section{THE JAMAICAN HEALTH TOURISM SECTOR AND THE CUSTOMER AS A VALUABLE RESOURCE}

Gouthier and Schmid (2003) assert that "the higher the extent of customer integration, the higher the potential of the service customer to constitute a resource" (p. 126). While some services involve relatively little customer integration (e.g., tax preparation, home maintenance services), others involve high levels of customer integration. Health tourism clearly falls into the latter category. With medical tourism encompassing procedures such as surgeries and dental services and wellness tourism involving treatments and experiences involving the service customer's use of his/her body (e.g., messages, yoga, meditation), it is clear that this sector involves high 
levels of customer integration. Therefore, there is great potential for the customer to serve as a resource to the service provider and the entire health tourism sector.

Referring to Gouthier and Schmid's (2003) conceptualization of the service "production process" (as previously referenced), the following highlights one of the five elements, namely pre-production input. The emphasis here is on pre-production input because by all accounts, Jamaica's health tourism sector is still in its infancy relative to several other countries. In addition, the following suggests how health tourism customers might play one of the add-on roles in the service production process (as a co-designer) as identified by Gouthier and Schmid (2003).

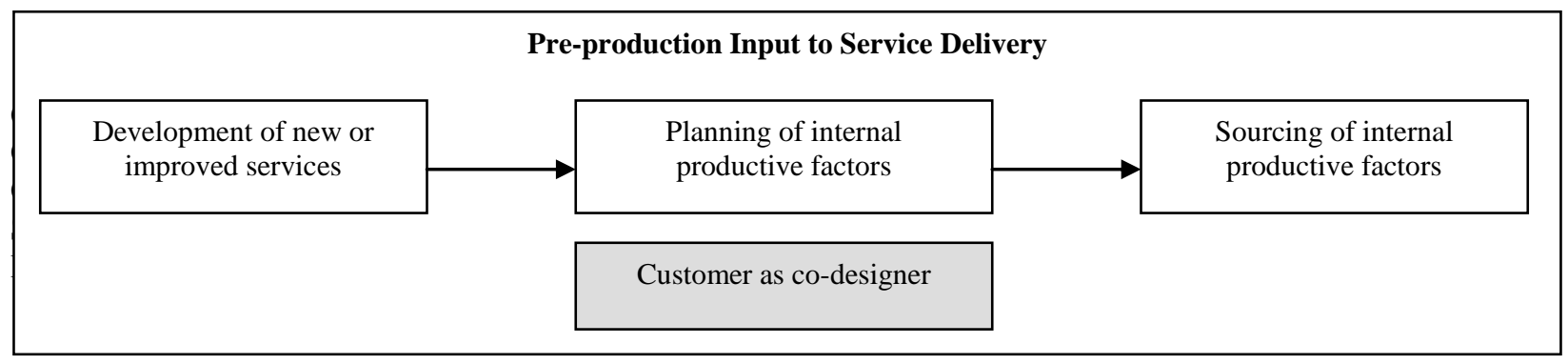

Figure 1 - slightly adapted from Gouthier and Schmid (2003)

\section{Development of new or improved services}

The tourism report in Jamaica's Vision 2030 Plan acknowledges that a significant segment of travelers now seek additional forms of active and meaningful travel experiences, which has given rise to the prevalence of the health tourism sector (Vision 2030 Jamaica 2010). Given the sole focus on the "traditional" Jamaican vacation of "sun, sea and sand" might not prove to continue to be a source of competitive advantage for Jamaica into the future, Vision 2030 Jamaica provides the foundation for the Island to develop services in alternative tourism sectors and to enhance existing ones. Some indicators that Jamaica is looking to provide offerings to take advantage of current and projected demand in the health tourism market include a number of multi-million dollar renovations that have taken place to add, expand, or improve existing hotel spas and wellness centers and efforts to increase the selection of wellness offerings.

In addition to the Jamaican government's expectation that the health tourism sector will play a key role in its competiveness, The Inter-American Development Bank (IDB) also projects steady growth in the Caribbean and Latin America region (Positive Tourism 2010). Consequently, the IDB made a substantial economic commitment to Island states within the Caribbean, including Jamaica to promote social and economic development within the health tourism sector (Positive Tourism 2010). In addition to economic support, the IDB conducted at least two forums that were intended to establish the foundation and set the course for five Caribbean nations, including Jamaica to develop and maintain a successful health tourism sector (Positive Tourism 2010). Further, the Caribbean Export Development Agency and the Caribbean Spa and Wellness Association developed a project intended to assist a number of countries, including Jamaica in the task of expanding and marketing its health tourism offerings in the Caribbean (International Medical Travel Journal 2010).

\section{Planning and Sourcing of Internal productive factors}

The Commonwealth Secretariat has recently made a commitment to providing technical assistance to JAMPRO for the purpose of developing and enhancing a viable medical tourism industry on Jamaica (Jamaica Gleaner 2010). An early step in this process is for JAMPRO to engage in the development of broad strategies. This is to take place in two phases. The first entails the assessment of Jamaica's competitiveness in the sector and the second involves research to identify success factors and make legal, regulatory, training and marketing plans (Commonwealth Secretariat 2010). It is clear that Jamaica is the pre-production stage in this sector, with early steps in planning of internal productive resources. 
Internal productive factors are can be viewed as those supplies, stocks, capabilities and/or competencies that must be possessed by the firm (or in this case, the sector) in order to render medical and/or wellness services. An important factor in providing health tourism offerings is facilities. JAMPRO notes that Jamaica seeks to exploit the projected growth trend in the health tourism industry by developing additional spa facilities, enhanced retirement communities, and hospitals and other facilities catering to tourists seeking medical treatments (JAMPRO 2010 ${ }^{1}$ ). Jamaica will also need to assess the quantity and quality of its medical facilities and match its supply of facilities with its desired growth in demand for medical tourism. According to Forrester and Belnavis (2008) Jamaica has 22 hospitals with 4,722 beds and an occupancy rate of 56.6\%, 348 health centers, 2,500 physicians, 4,374 nurses and over 100 imaging facilities and labs. Further, in Jamaica's quest to advance a sophisticated medical tourism sector, it should ensure that its facilities take advantage of the national telemedicine project platform (integrated voice/data/video health service delivered via secure broadband technology), which is now in place (JAMPRO $\left.2010^{2}\right)$.

In addition to medical facilities, wellness treatments and experiences are rendered in several different types of facilities, including large spas located in luxury hotels and all-inclusive resorts, smaller boutique hotels and extremely private villas that provide specialized attention and customized services often to 10-12 or fewer guests. Stand-alone wellness experiences, such as Day spas have also grown in prevalence, especially in the capital of Kingston (JAMPRO 2010²).

Given medical tourists place their physical well-being in the hands of medical professionals and procedures as well as the associated after-care can potentially mean the difference between life and death, the level of medical professionals' knowledge and skills is of paramount importance. Ashley, et al. (2004) notes that Jamaica enjoys a strong reputation for the existence of well-trained medical professionals and ability to provide solid health care at a relatively low cost on a per capita basis. Nevertheless, the data (or lack thereof) suggest that significant numbers of consumers do not travel to Jamaica to receive medical services and those who do, tend to be Jamaican-born individuals who now live abroad. If Jamaica is to grow its medical tourism sector, it must implement strategies to educate and train the required number of high-quality medical professionals, reduce "brain drain" with Jamaicaneducated professionals leaving the Island, and/or attract world-class medical professionals from outside the country to address the desired increase in demand.

In addition to facilities and human resources, an internal productive factor that is important to the health tourism sector is Jamaica's natural resources. The research of Voigt, et al. (2010), which examined wellness tourism, revealed that all respondents felt that attractive, environmentally lush surroundings were important in their experience. Jamaica has the opportunity to capitalize on the existence of pristine waters, lush foliage, and beautiful natural settings as well as several areas where tourists can escape from the crowds to unspoiled locations. A specific internal productive factor that has the potential to play an important role in Jamaica's health tourism sector is the existence of two natural mineral springs that address a growing trend of travelers "taking to the waters" to help individuals improve their health and well-being (Charlier \& Chaineux (2009).

According to a consultant general surgeon, who spoke to a group of Jamaican medical professionals, two significant challenges in the medical tourism sector include lack of appropriate equipment in public and private hospitals, and less-than-optimal experience on the part of health providers in specific areas such as joint replacement, organ transplants, and coronary artery bypass, which are highly demanded (East 2008). Clearly, these challenges require substantial attention if Jamaica is to effectively compete in the sector. Sourcing these internal productive factors will require time and significant financial investment from the Jamaican government and private entities.

\section{The Customer as a Co-designer}

As previously noted, the customer can play a vital role in helping firms (or sectors) enhance their offerings. In order for the customer to serve as a co-designer in the service production process, he/she must have a means by which to provide input. A logical starting point is for as many stakeholders as possible involved in the Jamaican health sector to collect data via survey and interviews from departing travelers as well as previous visitors to the Island. This could take the form of highly coordinated efforts on the part of government agencies, hotels and 
resorts, medical and wellness facilities/professionals the two major airports, etc. The data collected should focus on customers' experiences, expectations, attitudes, perceptions and purchase intentions with the goal of assessing current performance and specifics related to unfulfilled demand in the sector. In collecting the data, the appropriate parties should pay particular attention to the myriad of factors that impact consumers' decision to engage in health tourism. For example, Gan and Frederick (2011) cite numerous studies on the medical tourism sector that found that many different factors impact consumers' decision to choose a particular medical tourism destination. These include: the country's legal system, political/social stability, similarity with one's own culture, availability of nontraditional treatments, medical professional-to-customer ratio, cultural and religious sensitivity, reputation, convenience, quality of care, and confidentiality/care of records.

To ensure useful data are collected, it is important to understand the nature and composition of the (intended) target market. Currently, travelers from the US constitute the majority of visitors to Jamaica. However, an important question that must be answered is - within the US market, which demographic and lifestyle characteristics help define the health tourism market? This question is important because the composition of the "sea, sun, and sand" market could easily be quite different from that of the health tourism market. For example, Gan and Frederick (2011) found that income, age, and education influenced consumers' decisions to engage in medical tourism. In terms of markets, it is also vital to ascertain whether the potential to grow additional markets beyond the U.S. exists. For example, the Canadian and UK markets might also be attractive because they are English-speaking and spend massive amounts of money on healthcare. In fact, JAMPRO $\left(2010^{1}\right)$ reports that combined with the US, consumers from Canada and the UK spend approximately US $\$ 2.3$ trillion on healthcare.

When a firm or sector engages in any form of long-term planning, it is vital to assess the relevant 4Ps of marketing, which are: the product (or service), the price, the place and the promotion. In terms of the service itself, customer input should be solicited with respect to the type of health tourism services they desire. This means exploring the development of new and/or improved services. This is important because health tourism encompasses so many different types of treatments and experiences, including wellness offerings such as yoga and meditation, New Age, and holistic spiritual experiences, beauty treatments, sports \& fitness, and pampering. In the realm of medical tourism, it is vital to gain input on expectations and desired outcomes associated with cosmetic and other surgeries, dentistry as well as illness-related rehabilitation and healing or recuperation. In addition to the existence of different types of health tourism offerings, the types of issues, which travelers value varies. For example, a Mintel Consumer Report (2007) found that wellness tourists tend to be more concerned with their impact on the natural environment than other travelers and often seek out environmentally-friendly travel experiences. Wellness tourism providers must solicit input from (potential) consumers to discover how this concern translates into specific needs and how these consumers define "environmentally-friendly", "green", "eco-friendly", "natural", etc.

Customers input on pricing can prove to be helpful as well. Research indicates that many consumers engage in medical tourism in order to access lower-cost medical treatments. Some important questions that customers might answer include - what pricing strategy will ensure that Jamaica becomes more attractive for specific medical procedures than countries with established medical tourism reputations (e.g., Thailand, India)? An additional question is: what types of financial trade-offs (if any) do customers make? This involves customers' perceptions about the cost of airfare, the procedure itself, expenses associated with the recuperation period, to name a few. In addition, price perceptions and cost trade-offs will likely be quite different between medical tourists and wellness tourists. While a medical tourist might be highly motivated to travel to a particular destination by quality service at a low-cost, the cost could easily be far less of an issue to the wellness tourist. In fact, there is a segment of wellness tourists who seek luxurious, high-end services such as spa treatments and pampering and they are willing to pay a premium price.

Customer data regarding "place" would also prove to be beneficial to the Jamaican health tourism sector. Customer input on where they would like to receive medical and wellness treatments and services is a key element of providing new and/or improved offerings. This should include understanding consumers' preferences for location on the Island as well as the type of facility desired. Jamaica is a diverse Island with different areas known to provide divergent tourism experiences ranging from urban to very remote, and mountainous to seaside, for example. In addition, when considering wellness tourism, a number of different types of facilities exist; including large and small hotels, all-inclusive resorts, simple cottages, and private villas. Customer preference can vary widely. 
Clearly, for medical tourism, the type of facility is far more limited, with hospitals and clinics being the primary locations for procedures and treatments to take place. With both medical and wellness facilities, opportunities exist for customers to serve as a co-designers by providing input on what they value in a location and facility as well as the associated human/professional resources employed by the facility and the natural resources surrounding it and/or contributing to the delivery of services.

Finally, the manner in which the Jamaican health tourism sector is promoted will play a key role in its success. Once again, the customer can play a role of co-designer. Once the target market(s) is understood, in terms of demographics, lifestyles, preferences and other relevant factors, the marketing message can be appropriately crafted and disseminated based on their needs. Marketers of health tourism offerings should understand that reaching the wellness tourism customer and the medical tourism customer will likely take different approaches and particular care should be taken to match the promotion with the offering.

\section{CONCLUSIONS}

In conclusion, the health tourism sector appears to present viable opportunities for the Island of Jamaica and the country seeks to capitalize on the projected growth in this area. However, its current performance in this industry is not counted among one of its competitive strengths. This becomes apparent when considering the country's SWOT (strengths, weaknesses, opportunities and threats) analysis, which appears in the Vision 2030 Jamaica Plan (Vision 2030 Jamaica).

It appears that there is much work to be done to develop and maximize the existing infrastructure, knowledge base, natural resources, and customer base for Jamaica to reach its full potential in health tourism. Given the relatively early stage of Jamaica's presence in the sector, emphasis must be placed on the development of new and improved services as well as the planning and sourcing of internal productive factors. This will take the collective effort on the part of many, including: government agencies, existing tourism enterprises and organizations, aspiring health tourism entrepreneurs, educational institutions, academics/researchers, financial institutions, the international development community and very importantly, as noted in this study - the customer.

\section{AUTHOR INFOMRATION}

Dawn Pearcy, Ph.D. is an Associate Professor in the Marketing Department at Eastern Michigan University. She teaches and conducts research in the area of supply chain management. E-mail: dpearcy@emich.edu. Corresponding author.

Daria Gorodnia is a senior, marketing major at Eastern Michigan University and is the President of the International Business Student Association. E-mail: dgorodni@emich.edu

Jacquelyn Lester earned a BBA from Eastern Michigan University. She is currently pursuing a Master of Business Administration at Wayne State University and is a member of Delta Sigma Pi professional business fraternity. E-mail: cr8234@wayne.edu

\section{REFERENCES}

1. Amit, R. and Schoemaker, P.J.H. (1993). Strategic Assets and Organizational Rent. Strategic Management Journal 14(1), 33-46.

2. Asanuma, B. (1989). Manufacturer-supplier relationships in Japan and the concept of relation specific skill. Journal of the Japanese and International Economies, 3, 1-30.

3. Ashley, D; Gordon-Strachan, G. Reece, M. (2004). Challenges for health and tourism in Jamaica. Journal of Travel Medicine, 11(6), 370-373.

4. Barney, J.B. (1991). Firm Resources and Sustained Competitive Advantage. Journal of Management 17(1), 99-120.

5. Bitner, M.J., Booms, B.H. and Tetreault, M.S. (1990). The Service Encounter: Diagnosing Favorable and Unfavorable Incidents', Journal of Marketing 54(1), 71-84. 
6.

7.

of Vacation Marketing, 10(2), 122-137.

8. Chaharbaghi, K. \& Lynch, R. (1999). Sustainable competitive advantage: towards a dynamic resourcebased strategy. Management Decision, 37(1), $45-50$.

9. Charlier, R \& Chaineux, M. (2009). The healing sea: A sustainable coastal ocean resource: Thalassotherapy. Journal of Coastal Research, 25(4), 838-856.

10. Chen, C., Chen, S. and Tau, H. (2011). The destination competitiveness of Kinmen's tourism industry: exploring the interrelationships between tourist perceptions, service performance, customer satisfaction and sustainable tourism. Journal of Sustainable Tourism, 19(2), 247-264.

11. Commonwealth Secretariat (2010). Jamaica medical tourism development plan. Retrieved September 9, 2011 from http://www.thecommonwealth.org/Shared_ASP_Files/GFSR.asp?NodeID=230584\&AttributeName=File.

12. Connel, J. (2006). Medical tourism: sea, sun, sand and...surgery. Tourism Management, 1093-1100.

13. Conner, K.R. (1991). A Historical Comparison of Resource-Based Theory and Five Schools of Thought Within Industrial Organization Economics: Do We Have a New Theory of the Firm? Journal of Management 17(1), 121-54.

14. Dyer, J. \& Singh, H. (1998), The Relational View: Cooperative Strategy and Sources of Interorganizational Competitive Advantage. The Academy of Management Review, 23(4), 660-679

15. East, J (2008), Jamaica as a health tourism destination: Pipe dream or opportunity. Medical Association of Jamaica Symposium. Retrieved September 4, 2011 from

http://www.medicalassnjamaica.com/education.html.

16. Forrester, B \& Belnavis, W (2008). Health and wellness tourism: Why Jamaica. Presentation given on behalf of Jamaica Trade and Invest and New Lifestyle Holistic Health Spa and Clinic at Exporting Services to Canada Seminar. Retrieved September 1, 2011 from http://www.carib-export.com/.

17. Freiling, J. (1997). Relationships as Resources: Implications of the Resource-based View', in F. Mazet, R. Salle and J.P. Valla (eds) Interaction, Relationships and Network in Business Markets, pp. 249-77. Competitive paper presented at the 13th IMP Conference, Lyon.

18. Gan, L. \& Frederick, J. (2011). Consumers' Attitudes Toward Medical Tourism. Available at SSRN: http://ssrn.com/abstract=1837062.

19. Goodrich, J (1993) Socialist Cuba: A study of health tourism. Journal of Travel Research, 32(1), 36-40.

20. Goodrich, J \& Goodrich G(1987). Health-care tourism - An exploratory study. Tourism Management, 8(3), 217-222.

21. Gouthier, M. \& Schmid, S. (2003). Customers and Customer Relationships in Service Firms: The Perspective of the Resource-based View. Marketing Theory, 3(1), 119-143.

22. Hall, C(1992). Adventure, sport and health tourism. Special Interest Tourism. (pp. 141-158). London, England: Belhaven Press

23. Hogan, J.E. and Armstrong, G. (2001). Toward a Resource-Based Theory of Business Exchange Relationships: The Role of Relational Asset Value', Journal of Business-to-Business Marketing 8(4), 3-28.

24. International Medical Travel Journal (2010) Caribbean: Health and wellness tourism is one of the fastest growing segments of global tourism. Retrieved September 9, 2011 from http://www.imtjonline.com/news/?entryid82=244209.

25. Jamaica Gleaner(2010) JAMPRO scores big with Commonwealth secretary. Retrieved September 8, 2011 from http://www.jamaica-gleaner.com/gleaner/20100927/lead/lead5.html.

26. JAMPRO (2010). Health tourism. Retrieved September 6, 2011 from http://www.jamaicatradeandinvest.org/index.php?action=investment \&id=6\&oppage=1\&optyp=mm.

27. JAMPRO (2010). Jamaica ready for health tourism. Retrieved September 10, 2011 from http://www.jamaicatradeandinvest.org/news 209.html.

28. McNeil, K \& Raggins, E(2005). Staying in the spa marketing game: trends, challenges, strategies, and techniques. Journal of Vacation Marketing, 11(1), 31-38. 
29. Mintel Consumer Research Report(2007). Holistic tourism - International - February 2007. Retrieved September 4, 2011 from http://academic.mintel.com.ezproxy.emich.edu/sinatra/oxygen_academic/search_results/show\&/display/id= $\underline{237166 .}$.

30. Montgomery, C.A. (1995). Of Diamonds and Rust: A New Look at Resources', in C.A. Montgomery (ed.) Resource-Based and Evolutionary Theories of the Firm: Towards a Synthesis, pp. 251-68. Boston, Dordrecht and London: Kluwer.

31. Oliver, C. (1997). Sustainable Competitive Advantage: Combining Institutional and Resource-based Views. Strategic Management Journal 18(9), 697-713.

32. Ostrom, A.L. and Roundtree, R.I. (1998). Factors Influencing Consumers' Performance of Co-Production Service Roles', in E.E. Scheuing, S.W. Brown, B. Edvardsson and R. Johnston (eds) Pursuing Service Excellence: Practices and Insights, pp. 13-20. New York: International Service Quality Association Inc ISQA.

33. Peteraf, M.A. (1993). The Cornerstones of Competitive Advantage: A Resource-based View. Strategic Management Journal 14(2), 179-91.

34. Positive Tourism(2010). Health and wellness tourism registers steady growth in the Caribbean and Latin America. Retrieved September 4, 2011 from http://positivetourism.com.

35. Rouse, M.J. and Daellenbach, U.S. (1999). Rethinking Research Methods for the Resource-Based Perspective: Isolating Sources of Sustainable Competitive Advantage. Strategic Management Journal 20(5), 487-94.

36. Scheyvens, R., \& Momsen, J. (2008). Tourism in small island states: From vulnerability to strengths. Journal of Sustainable Tourism, 16(5), 491-510.

37. Schneider, B. and Bowen, D.E. (1995). Winning the Service Game. Boston, MA: Harvard Business School Press.

38. Smith, M \& Kelly, C(2006). Wellness tourism. Tourism Recreation Research, 31(1), 1-4.

39. Smith, M \& Puczkó (2009). Health and wellness tourism. Burlington, MA: Elsevier.

40. Srivastava, R.K., Fahey, L. and Christensen, H.K (2001). The Resource-based View and Marketing: The Role of Market-based Assets in Gaining Competitive Advantage. Journal of Management 27(6), 777-802.

41. Storbacka, K. (1993). Customer Relationship Profitability in Retail Banking, Research Report No. 29, Swedish School of Economics and Business Administration, Helsinki.

42. United Nations World Tourism Organization (UNWTO). (2008). Tourism 2020 vision. Retrieved from http://www.unwto.org/facts/eng/vision.htm.

43. Voigt, C; Laing, J; Wray, M; Brown, G; Howat, G; Weiler, B \& Trembath, R(2010). Health tourism in Australia: Supply, demand and opportunities. CRC for Sustainable Tourism Pty, Ltd. Gold Coast, Queensland.

44. Vision 2030 Jamaica (2010). Tourism sector plan. Retrieved August 20, 2010 from http://www.vision2030.gov.jm/.

45. Webb, D. (2000). Understanding Customer Role and its Importance in the Formation of Service Quality Expectations. The Service Industries Journal 20(1), 1-21.

46. Wernerfelt, B. (1984). A Resource-based View of the Firm', Strategic Management Journal 5(2), 171-80.

47. _ (1995). The Resource-based View of the Firm: Ten Years After. Strategic Management Journal 16(3), 171-4.

48. Yoon, Y., Gursoy, D., \& Chen, J.S. (2001). Validating a tourism development theory with structural equation modeling. Tourism Management, 22(4), 363-372.

49. Zeithaml, V.A. (1981). How Consumer Evaluation Processes Differ Between Goods and Services', in W.R. George and J.H. Donnelly (eds) Marketing of Services, pp. 186-90, Proceedings. Chicago, IL: American Marketing Association. 